kriterium for den sande kristendom: den ældste trosbekendelse. - Paulus' breve afslører jo tydeligt nok, at det var den mundtlige forkyndelse af evangeliet, der var ældst. $\mathrm{Og}$ at det er i lyset af den trosbekendelse, der sammenfatter denne mundtlige forkyndelse, man som kristen må læse Det gamle Testamente. Mogens Müller udtrykker det i slutningen af sin artikel ganske klart sådan:

»Ved at føje Det Nye Testamente til jødedommens Bibel har kirken i virkeligheden gjort den til en anden bog, lagt sig fast på én besetmt af flere mulige forståelser. Så en »kristen« bog er Det Gamle Testamente alene ved at blive læst i lyset af Det Nye Testamente....

Jeg undrer mig kun over, at denne teologiske professor sætter ordet »kristen« i citationstegn. Det forekommer mig overflødigt, når man selv er kristen og anser den kristne forståelse af Det Gamle Testamente for videnskabeligt legitim: »én bestemt af flere mulige«. Det var jo Jesus selv, der indførte denne læsemåde.

\title{
Grundtvigs betydning for voksenundervisning i Tyskland
}

\section{Af Jens Holger Schjørring}

Norbert Vogel: Grundtvigs Bedeutung für die deutsche Erwachsenenbildung.Ein Beitrag zur Bildungsgeschichte. Verlag Jullius Klinkhardt, Bad Heilbrunn 1994.

Gennem de seneste år har den internationale interesse og forståelse for Grundtvig været i stadig vækst. Som verden ser ud, kan det ikke undre, at det $\emptyset$ gede fremmedsprogede indslag i Grundtvig-forskningen fortrinsvis fremkommer på engelsk. Altimens vi fra dansk side søger at følge og stimulere dette så meget som muligt, må vi ikke overse, at der også er en bemærkelsesværdig udvikling i gang i Tyskland. En milepæl i den tysksprogede Grundtvig-forskning udgjorde den af professor Paul Röhrig arrangerede konference i Köln i 1988, udgivet på tryk med titlen »Um des Menschen willen. Grundtvigs geistiges Erbe als Herausforderung für Erwachsenenbildung, Schule, Kirche und soziales Leben«, Deutscher Studienverlag 1991. Endvidere kan det imødeses med forventning, at der inden længe vil komme en tre binds udgave af Grundtvigs værker i ny oversættelse til tysk, redigeret af en forskningsgruppe under ledelse af K.E. Bugge, F. Lundgreen-Nielsen og T. Jørgensen.

Ind i denne sammenhæng hører endvidere en anselig række bidrag af individuelle forskere, herunder forfatteren til den bog, der her skal introduceres, Norbert Vogel fra universitetet i Tübingen. N. Vogel har allerede 
præsenteret sig for denne årbogs læsere med artiklen »Grundtvigs Schulgedanken aus deutscher Sicht«, Grundtvig Studier 1989-1990.

Den nu foreliggende bog er Norbert Vogels habilitationsskrift fra det det social- og adfærdsvidenskabelige fakultet ved universitetet i Tübingen.

Lad det være sagt straks: der er tale om en specialiseret, sprænglærd undersøgelse, hvis emne ikke er Grundtvig-receptionen i almindelighed, men derimod Grundtvigs betydning for voksenpædagogikken i Tyskland fra den tidligste begyndelse af Grundtvig-receptionen i det 19. årh.s midte til ca. 1920.

Det er afhandlingens sigte at argumentere mod den antagelig både i Danmark og Tyskland udbredte forestilling om en generel forståelseskløft mellem de to landes tradition. Over for dette forenklede billede vil dr. Vogel vise, at der faktisk gennem 150 år har været en tradition i Tyskland for reception og forarbejdelse af Grundtvigs skoletanker, herunder også deres relevans for voksenpædagogikken. Forfatteren $\emptyset$ nker på ingen måde at underspille, at de kendte politiske skillelinier har virket skelsættende ind på denne påvirkning og i perioder udgjort en spærrebom for et uhindret studium og en fordomsfri forarbejdelse af Grundtvigs tanker. Det skinner også igennem i bogen, at nationalistisk chauvinisme fra dansk side i flere sammenhænge har været en væsentlig del af forklaringen. Ikke desto mindre fremlægger bogen dog dokumentation for en bemærkelsesværdig udviklingslinie gennem knap hundrede år, begyndende helt tilbage omkring $1810 \mathrm{og}$ sluttende omkring 1920.

Norbert Vogel inddeler denne receptionshistoriske udvikling i tre perioder, hvis afgrænsning vel at mærke ikke i første række er dikteret af de politiske og krigshistoriske skæbnebegivenheder, men snarere af hovedfaserne indenfor folkeoplysningsidealernes virkningshistorie i Tyskland.

Den første periode lader dr. Vogel som allerede anført begynde omkring 1810 og række indtil 1890 , således at 1840 'rne kom til at betegne et afgørende gennembrud. Perioden var karakteriseret derved, at impulsen udgik fra Grundtvigs kristelige hovedtanker for først i en senere og afledet sammenhæng at nå til skole- og uddannelsesidealerne. Det betones ganske vist, at den nationale politik i Tyskland med dens anti-liberale og antidemokratiske tendens udgjorde en spærrebom for en bredere indflydelse fra Grundtvigs tanker med deres accentuering af frihedsidealerne (s. 21-22).

Den anden periode betegner et afgørende gennembrud for folkehøjskolerne på tysk grund. Det kom til oprettelse af et betydeligt antal skoler, ikke mindst naturligvis i Slesvig, såvel den nordlige som den sydlige del, men også i områder, der lå langt borte fra den danske grænse som f.eks. Württemberg.

Indflydelsen fra Grundtvig holdes frem i sammenligning med den samtidige tilegnelse af beslægtede impulser fra bl.a. England (traditionen med »university-extension «). Norbert Vogel argumenterer vedholdende for, at Grundtvigs skoleidealer indeholdt større dynamik i henseende til deres 
potentielle muligheder for at indgå $\mathrm{i}$ en sammenhængende teoridannelse om voksenoplysning, men viser også, at de rent faktisk fik stor gennemslagskraft.

Den tredie og sidste periode, der behandles, rækker fra slutningen af det 19. årh. indtil omkring 1920. I denne periode er hovedpersonen ganske klart A.H. Hollmann, men der var langt flere bemærkelsesværdige bidrag til den blomstring, som den af Grundtvig inspirerede voksenpædagogik blev vidne til gennem vort århundredes første årtier. Dr. Vogel lægger vægt på, at Grundtvig-receptionen bestod $\mathrm{i}$ såvel institutionelle og organisatoriske initiativer med grundlæggelse af skoler som også betydningsfulde bidrag til en teoridannelse. Det noteres, at Hollmann også blev oversat til dansk af A. Vedel med titlen »Den danske Folkehøjskole og dens Betydning for Udviklingen af en folkelig Kultur i Danmark « (1910) og velvilligt modtaget. Det er imidlertid historiens ironi, at denne lovende begyndelse til den dybtgående tilegnelse og forarbejdelse af Grundtvigs skoletanker og de dermed sammenhængende frihedsidealer snart efter blev trængt i baggrunden i Tyskland som følge af ændrede samfundsvilkår, herunder naturligvis fremfor alt nazismen, der blandt mange andre ulykker resulterede i en katastrofal fordrejning i billedet af nordisk folkekultur, førende helt ud i militant, arisk racefanatisme og antisemitisme.

Afhandlingen har sin styrke i drøftelsen af vekselvirkningen mellem den samfundsmæssige og kulturelle baggrund for Grundtvig-receptionen i Tyskland og den grundtvigske højskoletradition som impulsgiver. Derudover diskuterer Norbert Vogel i sine afsluttende overvejelser behovet for på den ene side at skabe et videnskabeligt fundament for voksenoplysningen, på den anden side at respektere den folkelige praksis-orienterede grundholdning, der også har præget udviklingen her i landet. Ligeledes behandles det komplekse og ømtålelige forhold mellem kirkens undervisning og en af kirken principielt uafhængig livsoplysning.

Der er således meget at hente i denne tætskrevne afhandling, der uden tvivl vil give forfatteren megen akademisk hæder. Fra dansk side kan man kun udtrykke anerkendelse og respekt. Som en lille sidebemærkning kan der dog være grund til et lille hjertesuk, fordi forfatteren ikke i højere grad gennemfører et helhedssyn på Grundtvigs forfatterskab, således at de kristelige, filosofiske, litterære, politiske og pædagogiske tanker indgik i en samlet helhed. Dette er der som ovenfor kort antydet værdifulde ansatser til i bogen, men man kunne godt have ønsket sig en sådan helhedsbetragtning ført mere konsekvent igennem. Som en lille detalje kan det anføres, at forfatteren, der ellers er særdeles velorienteret om danske forhold og omhyggelig med detaljerne i sin bog, ved en fejltagelse har angivet Grundlovsdag i Danmark som d.15. juni (s.25). Bortset herfra er der dog grund til at udtrykke forhåbninger om, at Norbert Vogel også fremtidigt vil kunne bidrage til en konstruktiv dialog mellem tysk og dansk forskningstradition om forståelsen af Grundtvig i internationalt perspektiv. 